\title{
Nitrogen addition inhibits total monoterpene emissions in subtropical forest floor of South China
}

\author{
Xingran Huang ${ }^{1}$, Lili Zheng ${ }^{1}$, Pingping Guo ${ }^{1,2}$, Zhigang $\mathrm{Yi}^{1}{ }^{\text {, }}$ \\ 1 Fujian Provincial Key Laboratory of Soil Environmental Health and Regulation, College of Resources and Environment, Fujian Agriculture \\ and Forestry University, Fuzhou 350002, China \\ 2 Minjiang River Estuary Wetland National Nature Reserve Administrative Office, Fuzhou 350002, China
}

\section{H I G H L I G H T S}

- Effects of $\mathrm{N}$ addition on MT fluxes from forest floor were first investigated.

- $\mathrm{N}$ addition inhibited MT emissions from forest floors, while increased for litter.

- MT emissions from the PF floor was significantly higher than those from the BF floor.

\section{GRAPHICAL ABSTRACT}

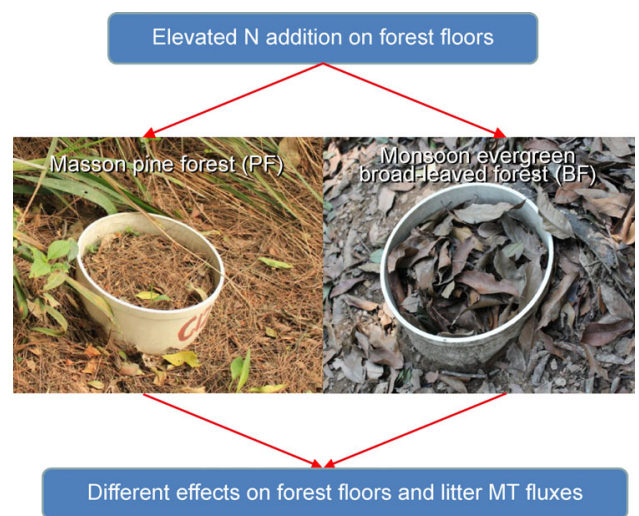

\section{A B S T R A C T}

Monoterpenes (MTs) play crucial roles not only in atmospheric chemistry and global climate change but also in soil processes and soil ecology. Elevated nitrogen $(\mathrm{N})$ deposition can influence soil microbial community and litter decomposition, and consequently alters MT fluxes from forest floors and litter. Yet, the responses of soil and litter MT to increased $\mathrm{N}$ deposition remain poorly understood and the influences of $\mathrm{N}$ addition are sometimes contradictory. In the present study, static chambers were placed in masson pine forest (PF) and in monsoon evergreen broad-leaf forest (BF) at Dinghushan, subtropical China. The preconcentrator-GC-MS was used to analyze the effect of $\mathrm{N}$ addition on MT fluxes from the forest floors and litter. The results showed that under control treatment (without $\mathrm{N}$ addition), the total MT emission rates were $279.90 \pm 137.17$ and $102.70 \pm$ $45.36 \mathrm{pmol} \mathrm{m}^{-2} \mathrm{~s}^{-1}$ in the PF and BF floors, respectively, with $\alpha$-pinene being the largest MT species in the PF and limonene in the BF. $\alpha$-pinene and $\beta$-pinene emission rates decreased significantly in both forest floors after $\mathrm{N}$ addition, whereas a diverse trend was found for limonene and camphene in the PF floor. Furthermore, some MT fluxes showed significant negative correlations with soil respiration and soil temperature. Litter was important in MT fluxes from forest floors and its emission rates were enhanced by $\mathrm{N}$ addition. Moreover, different MT response to elevated $\mathrm{N}$ was found between the forest floor and litter. This study indicated that the elevated $\mathrm{N}$ deposition in the future would inhibit the MT emissions from the subtropical forest floor.

(c) Higher Education Press 2020
* Corresponding author

E-mail address: zgyi@fafu.edu.cn (Z.G. Yi)

\section{Introduction}

Biogenic volatile organic compounds (BVOCs), released from plants, animals and microorganisms, have been estimated to 
have about $90 \%$ of volatile organic compounds (VOCs) (Guenther, 2002; Peñuelas and Llusia, 2003). Monoterpenes (MTs) are major BVOCs in the forest ecosystems, which not only play important roles in atmospheric chemistry and global change (Peñuelas and Staudt, 2010; Kivimäenpää et al., 2016), but they can also be recognized to have significant impacts on soil ecology and soil processes (Carriero et al., 2016; Maki et al., 2017). For example, MTs can influence soil nitrification (Smolander et al., 2012) and nitrogen (N) mineralization (Smolander et al., 2006), leading to the changes in $\mathrm{N}$ cycling and mediating interactions between microbes and plants (Wenke et al., 2009). Several studies have also shown that the MTs in forest floors can act as energy sources and it can be consumed by soil microorganisms (Owen et al., 2007; Greenberg et al., 2012) that are involved in plant growth and reproduction (Peñuelas and Staudt, 2010; Agathokleous et al., 2018). Lastly, MTs from the soil and litter can be metabolized to $\mathrm{CO}_{2}$ by microbes in soil or litter or be photo-oxidized to $\mathrm{CO}_{2}$ in the atmosphere (Owen et al., 2007; Insam and Seewald, 2010; Peñuelas et al., 2014), which also have played great roles in carbon balance and material cycle in forest ecosystem. However, recent studies on BVOCs are primarily focused on vegetation emissions (Greenberg et al., 2012; Agathokleous et al., 2018), with relatively limited attention to the forest floor (Asensio et al., 2007a; Leff and Fierer, 2008; Albers et al., 2018).

According to previous researches, forest floors can act as sources for BVOCs. They are considered to originate from several sources (Aaltonen et al., 2013; Maki et al., 2017), such as litter (Kainulainen and Holopainen, 2002; Gray et al., 2010), plant roots (Lin et al., 2007; Aaltonen et al., 2013) and soil microorganisms (Ramirez et al., 2010; Greenberg et al., 2012; Zhang-Turpeinen et al., 2019). However, other studies have also reported that forest floors operate as sinks rather than sources (Smolander et al., 2006; Asensio et al., 2007a; Owen et al., 2007), which could be partly attributed to the biodegradation of forest BVOCs by soil microorganisms and root tissue (Ramirez et al., 2010; Albers et al., 2018; SchulzBohm et al., 2018). In addition to the biotic processes, some abiotic processes, including soil porosity, were found to be involved in BVOC adsorption in the forest floor (Serrano and Gallego, 2006; Peñuelas et al., 2014). Furthermore, soil BVOC fluxes were indirectly affected by environmental parameters for regulating biological processes (Asensio et al., 2007a; Asensio et al., 2008; Insam and Seewald, 2010). Thus, the amount of nitrogen input, which can affect soil physicochemical properties, soil nutritional status and soil microbial community, may influence forest floor MT fluxes.

Nitrogen deposition, one of the main $\mathrm{N}$ inputs in natural forests as well as one of human-induced global change responsible, is thought to alter biodiversity and ecosystem function, arousing great concern (Bobbink et al., 2010; Zhang et al., 2017a). Additionally, it is expected to increase approximately 2.5-fold by 2100 (Galloway et al., 2008). An uptrend in the continuous emissions of $\mathrm{N}$ has been reported in China since the 1980s (Zhang et al., 2007), causing China (especially southern China) to be the third largest $\mathrm{N}$ deposition area in the world, followed by Europe and the United States (Galloway et al., 2004). Numerous studies have shown that the $\mathrm{N}$ addition can change the soil microbial community (Wang et al., 2015; Zhang et al., 2017a), accelerate litter decomposition (Schuster, 2015; Zhang et al., 2017b) and reduce plant diversity (Zeng et al., 2016; Zhang et al., 2017a). All these factors have been found to affect the structure and the function of forest ecosystems (Bobbink et al., 2010), and hence to influence BVOC fluxes from forest floor (Carriero et al., 2016; Kivimäenpää et al., 2016).

However, previous studies about the response of BVOC fluxes to elevated $\mathrm{N}$ deposition were mainly focused on vegetation (Carriero et al., 2016; Hu et al., 2018), with little on forest floor (Peñuelas and Staudt, 2010; Gray and Fierer, 2012), and even the limited available results of $\mathrm{N}$ addition on BVOCs from plants are sometimes inconsistent. Blanch et al. (2007) reported a positive effect of $N$ addition on BVOC emissions from Pinus halepensis and Quercus ilex. Similar results of terpenoid production increment due to $\mathrm{N}$ addition, were also found by Ormeño and Fernandez (2012). However, Kivimäenpää et al. (2016) found that additional $\mathrm{N}$ input to soil decreased BVOC emission in Pinus halepensis seedlings. Furthermore, the response of BVOC emissions to $\mathrm{N}$ addition varied between BVOC species. More specifically, a-pinene and $\beta$-pinene emissions were decreasing whereas ocimene, hexanal and (E)-4,8-Dimethyl-1,3,7-nonatriene emissions were increasing in Betula pendula (Carriero et al., 2016). To determine the response of MT fluxes to $\mathrm{N}$ addition in lowsubtropical forests of China, which are currently enduring high-N deposition, two different forests were selected. For this purpose, different $\mathrm{N}$ addition levels were set in the Dinghushan Biosphere Reserve (DBR). Our aims focused on (1) the amounts of MT fluxes from forest floors and litter, and the variation between different forest types, and (2) the different response of MT fluxes from forest floors and litter to elevated nitrogen deposition.

\section{Materials and methods}

\subsection{Site description and experimental treatments}

An experiment was performed in a masson pine forest (PF) and a monsoon evergreen broad-leaved forest (BF) at Dinghushan Biosphere Reserve (DBR), which is located in the middle of Guangdong Province, southern China (23 $10^{\prime} \mathrm{N}$ and $112^{\circ} 33^{\prime} \mathrm{E}$ ). The DBR experiences a typical subtropical monsoon climate, with annual average precipitation of 1927 $\mathrm{mm}$ and temperature of $21.4^{\circ} \mathrm{C}$, respectively. The ambient wet $\mathrm{N}$ deposition in this region in 2006 was about $56 \mathrm{~kg} \mathrm{~N} \mathrm{ha}^{-1} \mathrm{yr}^{-1}$ (Liu et al., 2008). The PF, dominated by Pinus massoniana species, is $\mathrm{N}$ reduced because of continuous human disturbances (usually the harvesting of understory and litter). However, the BF is $\mathrm{N}$ saturated since both long-term high- $\mathrm{N}$ deposition in the DBR and its relatively undisturbed state. Here the main canopy species are Castanopsis chinensis, 
Machilus chinensis, Schima superba, Cryptocarya chinensis, and Syzygium rehderianum. Detailed information about the site description and experimental design can be found in Mo et al. (2006).

As the first permanent $\mathrm{N}$ deposition research sites in China, three $\mathrm{N}$ treatments $\left(\mathrm{NH}_{4} \mathrm{NO}_{3}\right.$ solution sprayed on forest floor) have been established in PF and BF since 2003: (1) control (0 kg N ha ${ }^{-1} \mathrm{yr}^{-1}$, without $\mathrm{N}$ addition), (2) low-N (50 kg N ha ${ }^{-1} \mathrm{yr}^{-1}$ ) and, (3) medium-N (100 kg N ha $\left.{ }^{-1} \mathrm{yr}^{-1}\right)$. An additional high- $\mathrm{N}$ treatment (150 kg N ha ${ }^{-1} \mathrm{yr}^{-1}$ ) was established in the BF. Each $N$ treatment had three replications, resulting in 9 plots and 12 plots located in the PF and BF, respectively. Soil physicochemical properties of the forests are available from the study of Huang et al. (2012).

\subsection{Sample collection}

In the middle of March 2012, MT fluxes were randomly determined with a closed static chamber technique on each plot of PF and BF floors. The static chamber (ca. $17 \mathrm{~L}$ ) consisted of a bottom collar $(25 \mathrm{~cm}$ diameter and $10 \mathrm{~cm}$ height) with $5 \mathrm{~cm}$ buried in soil layer, a cover chamber $(25 \mathrm{~cm}$ diameter and $30 \mathrm{~cm}$ height), and inner walls all coated with Teflon film. A Teflon fan was fixed inside the chamber in order to mix well the air inside. Approximately $0.5 \mathrm{~L}$ air samples inside the chamber were collected into Tedlar bags by pump (SKC Inc., GA, USA) after closing the static chamber at 0 and $30 \mathrm{~min}$. Subsequently, the samples were stored away from light under low temperature condition and analyzed within three days after transferred to the laboratory. Soil temperature at $5 \mathrm{~cm}$ depth and soil water content inside the chamber were determined synchronously by a digital thermocouple (TES, Ltd, China) and a capacity probe (Delta-T ML2X Devices Ltd., England), respectively.

The effects of $\mathrm{N}$ addition on MT emissions from litter were also determined. Briefly, litter (litter layer, ca. $40 \mathrm{~g}$ ) were randomly collected in the field, near the chamber, and held in a $5 \mathrm{~L}$ sealed Teflon bag under light-free conditions for $30 \mathrm{~min}$. Approximately $0.5 \mathrm{~L}$ air samples were collected in Tedlar bags at 0 and $30 \mathrm{~min}$ after the Teflon bag sealed, and another $0.5 \mathrm{~L}$ air was put into the Teflon bag after 0 min sucking air for keeping the total volume balance. The dry mass of litter was measured after been dried in the oven at $60^{\circ} \mathrm{C}$ for $48 \mathrm{~h}$.

\subsection{Sample analysis}

A preconcentrator (7100A, Entech, USA) coupled with a gas chromatograph-mass spectrometer (GC-MS, 7890A-5973N, Agilent Technologies, USA) was employed for the MT analysis. Briefly, $0.25 \mathrm{~L}$ air samples were drawn from the Tedlar sample bags and were concentrated by the first cryogenic trap at $-160^{\circ} \mathrm{C}$ to trap the target compounds. Then, the first-stage trap was heated to a temperature of $10^{\circ} \mathrm{C}$, and the trapped gases were transported to the secondary trap at $-50^{\circ} \mathrm{C}$. After this stage, most of the $\mathrm{H}_{2} \mathrm{O}$ and $\mathrm{CO}_{2}$ in the samples were removed. Then, the secondstage trap was heated to a temperature of $170^{\circ} \mathrm{C}$, and the desorbed gases were transferred to a third trap at $-170^{\circ} \mathrm{C}$. Finally, the third trap temperature was rapidly raised to $80^{\circ} \mathrm{C}$, and the target VOCs were transferred to the GC-MS. Details were described by Wang and Wu (2008).

An HP-1 capillary column $(60 \mathrm{~m} \times 0.32 \mathrm{~mm} \times 1.0 \mu \mathrm{m}$, Agilent Technologies, USA) was used, and the GC temperature program was set to an initial temperature of $10^{\circ} \mathrm{C}$ for 3 min, then increase of $5^{\circ} \mathrm{C} \min ^{-1}$ up to $120^{\circ} \mathrm{C}$, and subsequently at $10^{\circ} \mathrm{C} \min ^{-1}$ up to $250^{\circ} \mathrm{C}$, holding for $7 \mathrm{~min}$. Helium was used as carrier gas with a flow rate of $4 \mathrm{~mL} \mathrm{~min}^{-1}$. The MS was run in selected ion monitoring mode, with a mass/change of 93 for MTs as the target ion. Total MTs, including a-pinene, $\beta$-pinene, limonene, camphene, $\alpha$-phellandrene, $\beta$-phellandrene and terpinene, were determined and quantified using a mixed standard gas.

$\mathrm{CO}_{2}$ flux was analyzed using a gas chromatograph (HP4890D, Agilent Technologies, USA) coupled with a flame ionization detector. The carrier gas rate of helium was $30 \mathrm{~mL} \mathrm{~min}^{-1}$. The $\mathrm{CO}_{2}$ concentration was calibrated by standard gas.

\subsection{Calculations and statistics}

The MT and $\mathrm{CO}_{2}$ fluxes of the forest floor and the MT fluxes of litter were calculated according to Eq. (1) and Eq. (2), respectively:

$$
\begin{gathered}
F_{F}=\frac{\Delta C * V}{\Delta t * A} \\
F_{L}=\frac{\Delta C * V * R_{L}}{\Delta t * W}
\end{gathered}
$$

$F_{F}$ is the MT (pmol m$\left.{ }^{-2} \mathrm{~s}^{-1}\right)$ or $\mathrm{CO}_{2}\left(\mathrm{mg} \mathrm{m}^{-2} \mathrm{~h}^{-1}\right)$ fluxes of forest floor; $F_{L}$ (pmol m ${ }^{-2} \mathrm{~s}^{-1}$ ) represent the MT fluxes of litter; $\Delta C$ (pmol $\mathrm{m}^{-3}$ ) is the difference in MT or $\mathrm{CO}_{2}$ concentration between $0 \mathrm{~min}$ and $30 \mathrm{~min} ; V\left(\mathrm{~m}^{3}\right)$ is the volume of the static chamber $(17 \mathrm{~L})$ or Teflon bag $(5 \mathrm{~L}) ; \Delta t(\mathrm{~s})$ is the interval between two sampling times (30 $\mathrm{min}) ; A\left(\mathrm{~m}^{2}\right)$ is the basal area of the static chamber; $W(\mathrm{~kg})$ is the weight of dry mass for litter; and $R_{L}\left(\mathrm{~g} \mathrm{~m}^{-2}\right)$ is the residue of litter.

All data were verified for normality and homogeneity by using the Shapiro-Wilk and Levene's tests, respectively. Distributions that did not conform to homogeneity of variances or normality requirements were transformed. Statistical analysis was performed using SPSS $19.0 \mathrm{v}$, and a statistically significant difference was set at $P=0.05$ value. A post hoc examination was conducted to test the significance among the $\mathrm{N}$ addition rates using the least significant difference (LSD) test. The difference of MT fluxes between the PF and BF was tested by independent sample $t$ test. The difference in MT fluxes between forest floor and litter, in the same forest type, was also tested by independent sample $t$ test. Two-way analysis of variance was performed to test the effect of $\mathrm{N}$ addition rates and forest types on the MTs. Relationships between the MT fluxes and soil respiration, soil water content and soil temperature were studied by applying the Pearson's correlation test. 


\section{Results}

\subsection{MT fluxes in control plots}

The total MT fluxes of forest floor and litter were significantly higher in the control plot of PF than in BF (Fig. 1). In the PF control plot, the total MTs fluxes (including $\alpha$-pinene, $\beta$-pinene, limonene, camphene, $\alpha$-phellandrene, $\beta$-phellandrene and terpinene) of the forest floor and litter were $279.90 \pm 137.17$ and $8.56 \pm 1.20 \mathrm{pmol} \mathrm{m}^{-2} \mathrm{~s}^{-1}$, respectively. This suggests that both forest floor and litter, acted as sources for MTs in the PF (Fig. 1). Moreover, total MT fluxes were significantly higher in the forest floor than in the litter. Among the identified MT species, the PF forest floor acted as major source for $\alpha$-pinene $\left(220.30 \pm 159.54 \mathrm{pmol} \mathrm{m}^{-2} \mathrm{~s}^{-1}\right)$, followed by $\beta$-pinene $(29.611$ $\left.\pm 7.20 \mathrm{pmol} \mathrm{m}^{-2} \mathrm{~s}^{-1}\right)$; and as major sink for limonene $(-43.58 \pm$ $\left.3.24 \mathrm{pmol} \mathrm{m} \mathrm{m}^{-2} \mathrm{~s}^{-1}\right)$, followed by camphene $(-22.17 \pm 7.20$ pmol $\mathrm{m}^{-2} \mathrm{~s}^{-1}$ ) (Fig. 2). For the litter, the major individual MT fluxes were $\alpha$-pinene and $\beta$-pinene, with values of $4.18 \pm 1.13$ and 4.28 $\pm 0.04 \mathrm{pmol} \mathrm{m}^{-2} \mathrm{~s}^{-1}$, respectively (Fig. 3).

In the control plot of BF, the forest floor and litter acted as main sources for total MTs. The MT emission rates from the forest floor were significantly higher than those from the litter, with values of $102.70 \pm 45.36$ and $5.66 \pm 1.16 \mathrm{pmol} \mathrm{m}^{-2} \mathrm{~s}^{-1}$, respectively (Fig. 1). Furthermore, the BF floor acted as main source for limonene $\left(47.37 \pm 35.08 \mathrm{pmol} \mathrm{m}^{-2} \mathrm{~s}^{-1}\right)$, followed by $\beta$-pinene, camphene and $\alpha$-pinene, with emission rates of 8.77 $\pm 7.16,8.61 \pm 7.81$, and $7.66 \pm 8.95 \mathrm{pmol} \mathrm{m}^{-2} \mathrm{~s}^{-1}$, respectively

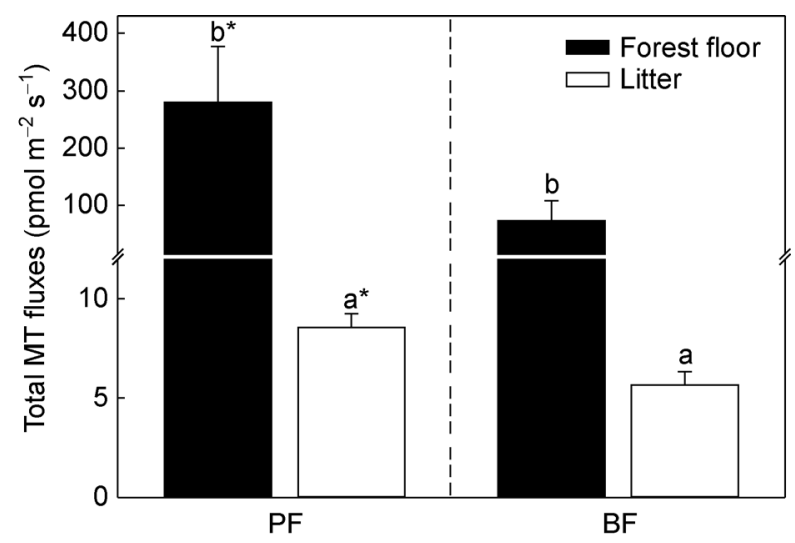

Fig. 1 Total monoterpene (MT) fluxes in control plots of masson pine forest (PF) and monsoon evergreen broadleaved forest (BF) of subtropical China. Vertical bars represent the standard errors of the means $(n=3)$. Different letters for a given forest indicate significant differences $(P<0.05)$ between forest floor and litter. Asterisks indicate a significant difference $\left({ }^{*}=P<0.05\right)$ between the PF and BF.
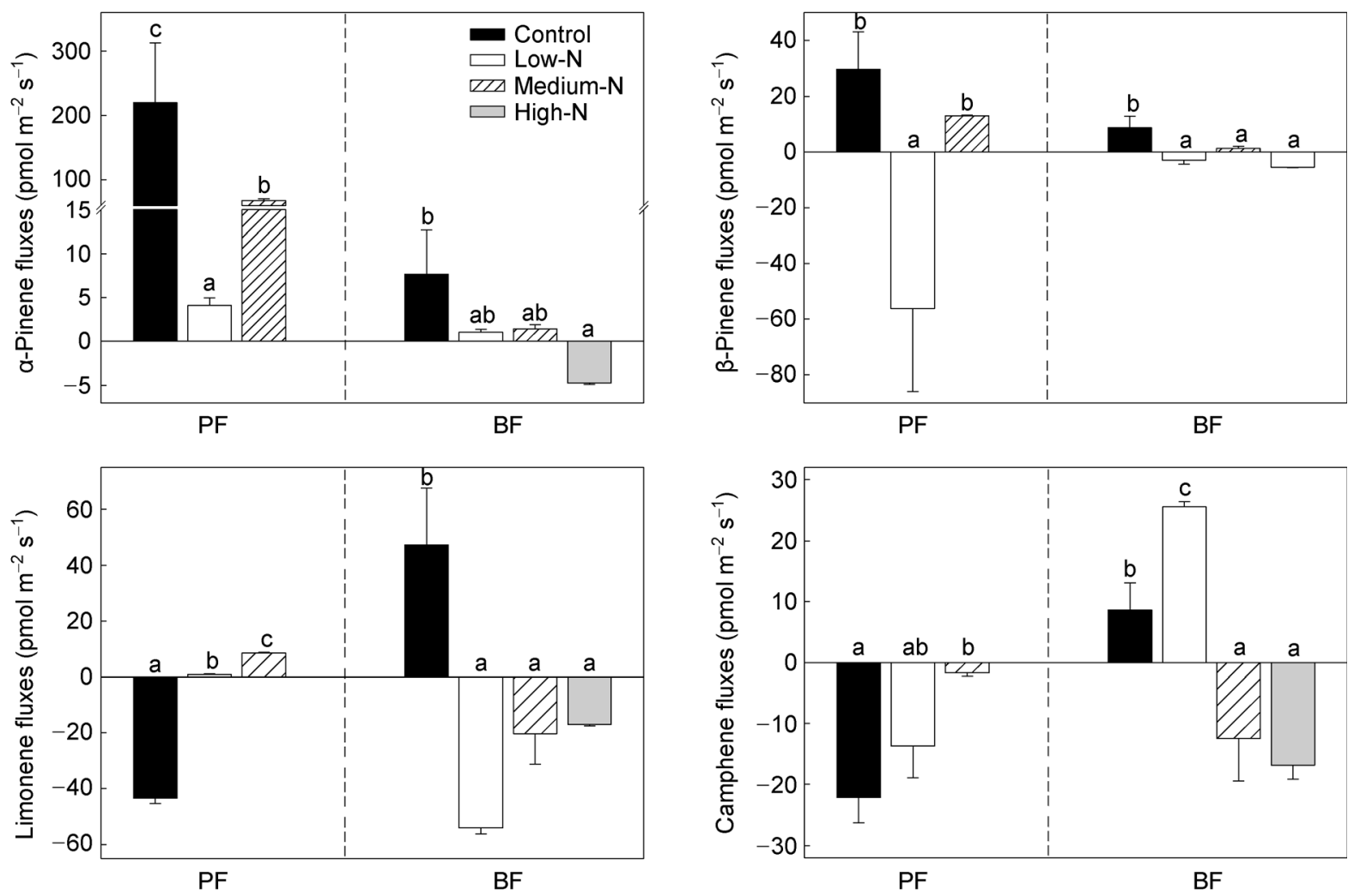

Fig. 2 Effects of nitrogen (N) addition on major monoterpene (MT) fluxes of the forest floor in the masson pine forest (PF) and monsoon evergreen broad-leaved forest (BF) of subtropical China. Vertical bars represent the standard errors of the means $(n=$ 3). Different letters for a given variable indicate a significant difference $(P<0.05)$ in the same forest among different $\mathrm{N}$ levels. 

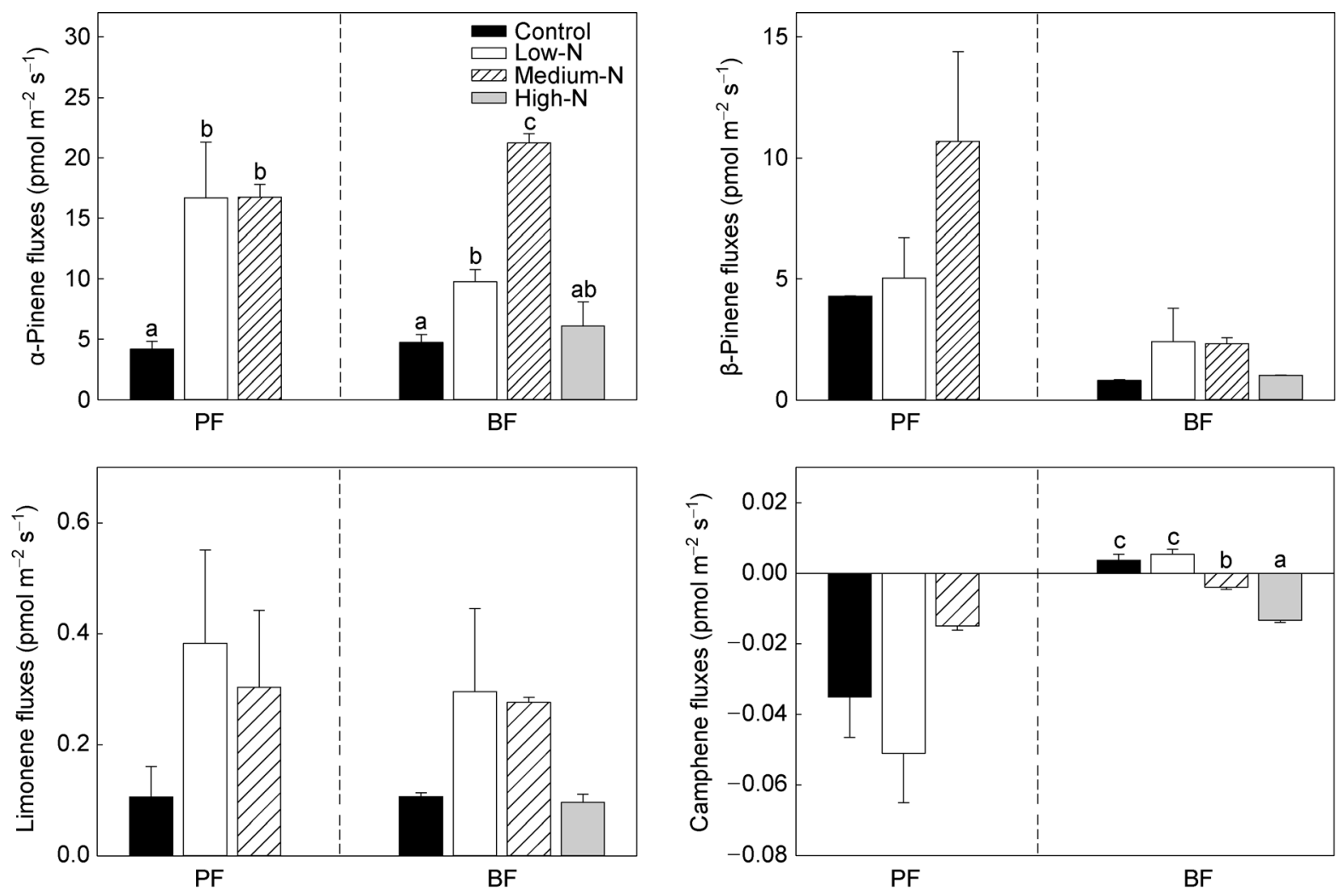

Fig. 3 Effects of nitrogen (N) addition on major monoterpene (MT) fluxes of the litter in the masson pine forest (PF) and monsoon evergreen broad-leaved forest (BF) of subtropical China. Vertical bars represent the standard errors of the means $(n=$ 3). Different letters for a given variable indicate a significant difference $(P<0.05)$ in the same forest among different $\mathrm{N}$ levels.

(Fig. 2). In addition, a-pinene was the dominant compound of MT in the litter, with emission rate of $4.73 \pm 1.13 \mathrm{pmol} \mathrm{m}^{-2} \mathrm{~s}^{-1}$ (Fig. 3).

\subsection{Effects of $\mathrm{N}$ addition on MT fluxes}

The responses of MTs to $\mathrm{N}$ addition varied according to forest type and $\mathrm{N}$ treatment level in both forest floor and litter (Figs. 2, 3 and 4; Table 1). For the forest floor, $\mathrm{N}$ addition, interaction of $\mathrm{N}$ addition and forest types, had significantly affected the total MT (including $\alpha$-pinene, $\beta$-pinene, limonene and camphene) emission in the PF and BF floors (Table 1). The total MTemission rates decreased significantly with $\mathrm{N}$ addition, and the forest floor even shifted from source to sink under the low$\mathrm{N}$ treatment in the PF floor (Fig. 4). For example, a-pinene emission rate decreased significantly by $98.1 \%$ in the low- $\mathrm{N}$ treatment and by $28.9 \%$ in the medium- $\mathrm{N}$ treatment, while $\mathrm{N}$ input also caused a decline in $\beta$-pinene emission or a shift from source to sink in the PF floor. Compared with the control treatment, the emission rates of limonene and camphene increased, and the PF floor changed from sink to source with elevated $\mathrm{N}$ addition (Fig. 2). Moreover, the total MT fluxes of $\mathrm{BF}$ floor had changed its function from source to sink in the forest floor, due to $\mathrm{N}$ addition, which caused a decrease in

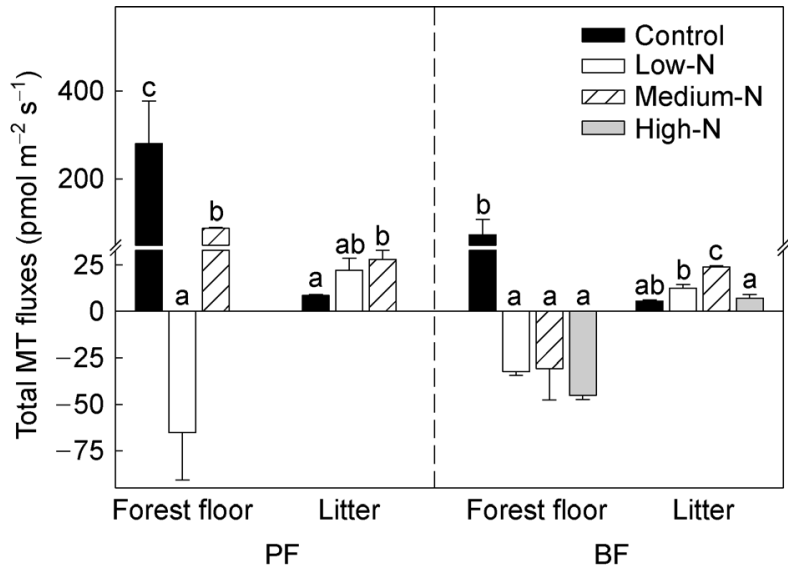

Fig. 4 Effects of nitrogen $(\mathrm{N})$ addition on total monoterpene (MT) fluxes of the forest floor and litter in the masson pine forest (PF) and monsoon evergreen broadleaved forest (BF) of subtropical China. Vertical bars represent the standard errors of the means $(n=3)$. Different letters for a given variable indicate a significant difference $(P<0.05)$ in the same forest among different $\mathrm{N}$ levels. 
total MT (i.e., $\alpha$-pinene, $\beta$-pinene, limonene and camphene) emission rates as compared to control conditions, especially under high- $\mathrm{N}$ treatment $(P<0.05$, Figs. 2 and 4). Furthermore, there was significant difference of total MT flux (mainly a-pinene and camphene) between PF and BF floor (Table 1).

For the litter, $\mathrm{N}$ addition significantly affected total MT emission (i.e., $\alpha$-pinene) in the PF and BF (Table 1). Total MT emission rates enhanced $(P<0.05)$ by $N$ addition in the PF litter, while it was not significantly affected on the fluxes of $\beta$ pinene, limonene and camphene (Figs. 3 and 4). Furthermore, the total MT (i.e., a-pinene) emission rates increased with increasing $\mathrm{N}(P<0.05)$ in the BF litter, but decreased with the high- $\mathrm{N}$ treatment. When comparing to the control treatment, the emission rate of BF litter camphene decreased with $\mathrm{N}$ addition (Figs. 3 and 4). Further, there were significant difference of $\beta$-pinene and camphene fluxes between PF and $\mathrm{BF}$ litter, and the interaction of $\mathrm{N}$ addition and forest types significantly affected $\beta$-pinene and camphene in the PF and BF litter (Table 1).

3.3 Correlation of forest floor MT fluxes with soil respiration, soil temperature and soil water content

At the experimental sites, soil temperature, soil water content and soil respiration were measured, and the relationships between these parameters of the MT fluxes were tested (Table 2). The results showed that total MT flux (i.e., $\beta$-pinene) in the PF floor $\left(R^{2}=0.575\right)$ and camphene flux in the BF floor $\left(R^{2}=0.648\right)$ had a negative correlation with soil respiration. In addition, soil temperature showed a significant negative linear correlation with total MT fluxes (i.e., $\alpha$-pinene and $\beta$-pinene) in the PF floor and total MT fluxes (i.e., $\beta$-pinene and limonene) in the BF floor, which implied that or these MT emission rates decreased with temperature or that the uptake rates increased with temperature. However, there was no obvious correlation between MT fluxes and soil water content in either forest floor (Table 2).

\section{Discussion}

\subsection{MT fluxes in the control plots}

Forest floors acted as sources for MTs in the control plots (0 kg N ha ${ }^{-1} \mathrm{yr}^{-1}$ addition, Figs. 1 and 2). The total MT emission rates, with values of $279.90 \pm 137.17$, and $102.70 \pm$ $45.36 \mathrm{pmol} \mathrm{m}^{-2} \mathrm{~s}^{-1}$ in PF and BF (Fig. 1), respectively. These rates were higher than those found in a Mediterranean holm oak forest floor (maximum 3 pmol m $\mathrm{m}^{-2} \mathrm{~s}^{-1}$, Asensio et al., 2008) and those in a Sitka spruce forest $\left(26 \mathrm{pmol} \mathrm{m} \mathrm{m}^{-2} \mathrm{~s}^{-1}\right.$, Hayward et al., 2001). Similarly, the fluxes of camphene $\left(8.61 \pm 7.81 \mathrm{pmol} \mathrm{m}^{-2} \mathrm{~s}^{-1}\right)$ and limonene $(47.37 \pm 35.08$ pmol $\mathrm{m}^{-2} \mathrm{~s}^{-1}$ ) in the BF floor (Fig. 2) were also significantly higher than those in the Mediterranean holm oak forest (0.4 and $-0.4 \mathrm{pmol} \mathrm{m}^{-2} \mathrm{~s}^{-1}$ for camphene and limonene, respectively) (Asensio et al., 2007b). In addition, $\alpha$-pinene, $\beta$ pinene and limonene were detected as the main MTs in our study (Figs. 2 and 3), which matched results from Hayward et al. (2001).

The MT emissions of forest floors could be derived from litter, since litter can be produced abiotically by volatilization or nonenzymatic thermochemical reactions (Hassiotis and Lazari, 2010; Greenberg et al., 2012) or biotically through microbial degradation (Kainulainen and Holopainen, 2002; Hassiotis and Lazari, 2010). The total MT emission rates from litter were $8.56 \pm 1.20 \mathrm{pmol} \mathrm{m}^{-2} \mathrm{~s}^{-1}$ in the PF and $5.66 \pm 1.16$ pmol m $\mathrm{m}^{-2} \mathrm{~s}^{-1}$ in the BF, estimated $3.06 \%$ and $7.67 \%$ of the respective forest floors (Fig. 1), indicating that forest litter represented a small MT source in our study. Greenberg et al. (2012) also found a small contribution of MT emissions from the leaf litter in ponderosa pine species (Pinus ponderosa). The contribution of MT emission, from litter to total MT fluxes, might be determined on the type, the amount, and the quality of the litter in different forests. For example, Ramirez et al. (2010) demonstrated that Pinus taeda and Acer rubrum litter emitted higher MTs than those from litter and soil together. Moreover, Kainulainen and Holopainen (2002) and Gray et al.

Table 1 Effects of nitrogen addition (N) and forest types (FT) on monoterpene (MT) fluxes of the forest floor and litter in the masson pine forest (PF) and monsoon evergreen broad-leaved forest (BF) of subtropical China.

\begin{tabular}{|c|c|c|c|c|c|c|c|c|c|c|}
\hline & \multicolumn{2}{|c|}{ Total MTs } & \multicolumn{2}{|c|}{$\alpha$-Pinene } & \multicolumn{2}{|c|}{$\beta$-Pinene } & \multicolumn{2}{|c|}{ Limonene } & \multicolumn{2}{|c|}{ Camphene } \\
\hline & $\mathrm{F}$ & $P$ & $\mathrm{~F}$ & $P$ & $\mathrm{~F}$ & $P$ & $\mathrm{~F}$ & $P$ & $\mathrm{~F}$ & $P$ \\
\hline \multicolumn{11}{|c|}{ Forest floor } \\
\hline $\mathrm{N}$ & 21.515 & $<0.001^{*}$ & 18.474 & $<0.001^{*}$ & 6.015 & $0.010^{*}$ & 11.241 & $<0.001^{*}$ & 14.276 & $<0.001^{*}$ \\
\hline FT & 13.386 & $0.003^{*}$ & 51.412 & $<0.001^{*}$ & 0.142 & 0.713 & 1.978 & 0.185 & 33.430 & $<0.001^{*}$ \\
\hline $\mathrm{N}^{*} \mathrm{FT}$ & 6.935 & $0.010^{*}$ & 24.064 & $<0.001^{*}$ & 5.352 & $0.022^{*}$ & 74.369 & $<0.001^{*}$ & 22.965 & $<0.001^{*}$ \\
\hline \multicolumn{11}{|l|}{ Litter } \\
\hline $\mathrm{N}$ & 12.034 & $<0.001^{*}$ & 19.333 & $<0.001^{*}$ & 2.148 & 0.140 & 2.340 & 0.118 & 2.418 & 0.110 \\
\hline FT & 4.254 & 0.058 & 0.143 & 0.711 & 13.211 & $0.003^{*}$ & 0.203 & 0.659 & 39.168 & $<0.001^{*}$ \\
\hline $\mathrm{N}^{*} \mathrm{FT}$ & 0.895 & 0.565 & 4.072 & $0.040^{*}$ & 1.807 & 0.200 & 0.095 & 0.910 & 5.432 & $0.018^{*}$ \\
\hline
\end{tabular}

Table shows the two-way analysis of variance results ( $F$ and $P$ values), asterisks representing statistical significance $\left({ }^{*}=P<0.05\right)$. 
Table 2 Correlation of the monoterpene (MT) fluxes of forest floor with soil respiration (SR), soil water content (SWC) and soil temperature (ST) in the masson pine forest (PF) and monsoon evergreen broad-leaved forest (BF) of subtropical China.

\begin{tabular}{|c|c|c|c|c|c|}
\hline & Total MTs & a-Pinene & $\beta$-Pinene & Limonene & Camphene \\
\hline \multicolumn{6}{|l|}{ PF } \\
\hline SR & $-0.758^{*}$ & -0.599 & $-0.670^{*}$ & 0.548 & 0.142 \\
\hline SWC & 0.473 & 0.444 & 0.354 & -0.635 & -0.363 \\
\hline ST & $-0.892^{*}$ & $-0.919^{* *}$ & $-0.674^{\star}$ & 0.645 & 0.239 \\
\hline \multicolumn{6}{|l|}{$\mathrm{BF}$} \\
\hline SR & -0.553 & -0.531 & -0.425 & -0.246 & $-0.805^{*}$ \\
\hline SWC & -0.026 & 0.306 & 0.223 & -0.222 & 0.251 \\
\hline ST & $-0.741^{*}$ & -0.475 & $-0.579^{\star}$ & $-0.871^{*}$ & 0.080 \\
\hline
\end{tabular}

Table shows the Pearson correlation coefficients, asterisks representing statistical significance $\left({ }^{*}=P<0.05,{ }^{* *}=P<0.01\right)$.

(2010) also showed that litter makes a not insignificant contribution to total soil VOC emissions.

Soil is another source of forest floor MTs (Ramirez et al., 2010; Greenberg et al., 2012; Zhang-Turpeinen et al., 2019). Fall and Copley (2000) found that the genera of Bacillus and Pseudonocardia emitted VOCs, and MTs will consequently affect associated microbial populations (Smolander et al., 2012). However, soil microbes were able to metabolize a wide range of VOCs as a carbon source (Owen et al., 2007; Aaltonen et al., 2012; Albers et al., 2018), making soil acted as sink for MTs. In addition, VOCs could be easily adsorbed by clay minerals (Serrano and Gallego, 2006; Peñuelas et al., 2014), and root tissues can also uptake or degrade some VOCs in soil solution (Cho et al., 2005; Lin et al., 2007; Aaltonen et al., 2012). Thus, the MT dynamics of forest floor, which are sources and sinks, are closely linked, thus leading to complex interactions (Schulz-Bohm et al., 2018).

\subsection{Response of forest floor MT fluxes to $\mathrm{N}$ addition}

The MT emission and uptake processes are strongly influenced by biological and environmental factors (Chomel et al., 2016; Maki et al., 2017), which had inhibited total MT emissions and even changed the function of forest floor after $\mathrm{N}$ addition (Figs. 2 and 3; Table 1). Methyl trophic bacteria and other microorganisms could catabolize some VOCs (including MTs) to $\mathrm{CO}_{2}$ (Owen et al., 2007). This will lead soil respiration (SR) to have significant negative correlations with total MT flux (i.e., $\beta$-pinene) in the PF floor and camphene flux in the BF floor (Table 2), in accordance with previous results reported by Leff and Fierer (2008) and Asensio et al. (2008). However, Gray and Fierer (2012) discovered that MT emissions from soil and litter were not related to $\mathrm{CO}_{2}$ production due to both VOC production and consumption associated with microbes occurring simultaneously (Insam and Seewald, 2010; Peñuelas et al., 2014), which might explain how some MTs of forest floor did not correlate with SR (Table 2). Furthermore, N inputs may influence MT fluxes by altering the community of microbial decomposer, which are involved in VOC production and, subsequently influences litter decomposition at different decomposition stages (Kainulainen and Holopainen, 2002; Grandy et al., 2013). Thus, the shifts in physiology and microbial community composition due to $\mathrm{N}$ addition could partly result in the decline of MT fluxes in forest floors (Figs. 2 and 4).

The impacts of simulated $\mathrm{N}$ deposition on individual MT fluxes of forest floors depended on MT species (Fig. 2; Table 1). The results were driven by various factors, such as soil microorganisms (Wenke et al., 2009), quality of substrates (Mancuso et al., 2015) and environmental conditions (Wang et al., 2010; Aaltonen et al., 2013) and/or the differences between litter and soil related to abiotic volatilization rates. For example, $\alpha$-pinene and $\beta$-pinene emission rates decreased under $\mathrm{N}$ addition in the PF and BF floors (Fig. 2; Table 1), which was partially consistent with Gray and Fierer (2012), who found that VOC emissions from litter were inhibited by $\mathrm{N}$ fertilization, and the relative contribution of individual VOCs could also be altered due to the increased liability of litter. However, limonene and camphene fluxes showed positive correlations $(P<0.05)$ with $\mathrm{N}$ addition in the PF (Fig. 2), implying that or limonene and camphene rates decreased or that emission rates increased with increasing $N$ addition. This is because the PF is a nitrogen limited forest (Mo et al., 2003; Mo et al., 2006), and additional nitrogen fertilization could stimulate soil microbial activities and thus, cause an increase in soil microbial biomass as well as litter decomposition (Schuster, 2015; Zhang et al., 2017b), hence accelerating some types of MT emissions from the forest floor (Fig. 2).

\subsection{The difference in MT fluxes between forest floor and litter}

Forest floor had larger MT fluxes than litter in the control plots (Figs. 1 and 4), which could be due to different reasons. First, some plant roots and rhizosphere systems could produce large amounts of BVOCs (Cho et al., 2005; Aaltonen et al., 
2013), including $\alpha$-pinene, $\beta$-pinene and limonene (Lin et al., 2007). Second, the activity of rhizospheric microbes is much higher than the root-free soil microbes, and they could use large amounts of root exudates to produce VOCs (Lin et al., 2007; Ramirez et al., 2010; Greenberg et al., 2012). Finally, we did not remove the litter inside the chamber in our forest floor measurements, due to its interaction with the surface soil and microorganisms. This will lead to higher emission rate in the control plots of forest floors (Fig. 1).

Total MT fluxes of litter exhibited positive correlations with additional $\mathrm{N}$ in our study; conversely negative correlations for forest floor (Fig. 4; Table 1). This could be attributed by our sampling design. We measured the litter MT emission rates (pmol $\mathrm{m}^{-2} \mathrm{~s}^{-1}$ ) just from ca. $40 \mathrm{~g}$ litter layer in the Teflon bag, which would cause the inaccuracy of MT emissions from the whole litter profile. In addition, we did not measure the MT emissions from rhizospheric microbes. $\mathrm{N}$ input might change the root exudates, which will stimulate microbial population in the rhizosphere (Wenke et al., 2009), thereby increasing VOC consumption (Asensio et al., 2007a). Furthermore, the increase of microbial activity could promote VOC endorsement at the soil-litter interface (Ramirez et al., 2010; SchulzBohm et al., 2018). Besides, although MTs released from litter varied significantly under different stages of litter decomposition (Grandy et al., 2013), the results still indicated that MT emissions from litter in subtropical forests of China, and its response to $\mathrm{N}$ addition, may be differs in relationship to the $\mathrm{N}$ status of the ecosystem (Figs. 3 and 4).

\subsection{The difference in MT fluxes between PF and BF}

The total MT fluxes of forest floor and litter in control plots treatment were significantly lower in the BF than in the PF (Figs. 1 and 4), which could be attributed to the variance of plant species and litter types in different forests. The dominant species is Pinus massoniana in the PF; however, the major species in the BF were Castanopsis chinensis Hance, Schima superba Gardner \& Champion, Cryptocarya chinensis (Hance) Hemsl, Cryptocarya concinna Hance, among them (Mo et al., 2006). Most studies reported that coniferous species emitted predominantly MTs (Aydin et al., 2014; Hu et al., 2018), and pine litter produces larger amounts of VOCs (including MTs) than other species (Guenther et al., 2012). In addition, Lin et al. (2007) found large number of a-pinene, limonene, $\beta$-pinene and camphene in Pinus roots, suggesting that Pinus is not a minor contributor to MT emissions from forest floors. Besides, the difference in soil characteristics between forest floors, is especially due to microbial community, microbial biomass, microbial decomposable activity, and enzymatic activity between PF and BF floor (Mo et al., 2003; Huang et al., 2012), since microbes produce some VOC species (Ramirez et al., 2010; Greenberg et al., 2012; Smolander et al., 2012) or sometimes consume VOCs as carbon source (Aaltonen et al., 2012; Albers et al., 2018).

Our results also showed that the influence of simulated $\mathrm{N}$ deposition on MT fluxes in the BF was more significantly higher than in the PF (Figs. 2, 3 and 4; Table 1). As reported, the PF was approximately planted in 1930 and then affected by human activities often and thus greatly degraded, causing low N content (Mo et al., 2003; Mo et al., 2006). Contrary to the PF, the BF had been likely well protected for 400 years and had abundant in nitrogen (Mo et al., 2003). Moreover, root biomass, microbial activity, and soil organic matter were documented to be higher in the BF than in the PF (Mo et al., 2003; Huang et al., 2012). As discussed above, VOCs in forest floors mainly originate from microbial activities and roots (Ramirez et al., 2010; Greenberg et al., 2012), and increased available $\mathrm{N}$ content that are beneficial to forest ecosystem biomass (Wang et al., 2015; Zhang et al., 2017a), which may result in a higher MT emission rates in response to $\mathrm{N}$ addition in the BF (Figs. 2, 3 and 4).

\section{Conclusions}

Monoterpene (MT) fluxes in response to nitrogen (N) addition were studied in the masson pine forest (PF) and monsoon evergreen broad-leaved forest (BF) in Dinghushan Biosphere Reserve (DBR) after nine years of $\mathrm{N}$ addition. In the control plots (no additional $\mathrm{N}$ ), forest floor and litter acted as sources for total MT fluxes, and the total MT fluxes in the PF were significantly higher than those found in the BF. Moreover, $\alpha-$ pinene and limonene were the dominant MTs components in the PF and BF floors, respectively. Generally, MT emissions from forest floors decreased or forest floors changed from source to sink after long-term $\mathrm{N}$ addition. Nonetheless, $\mathrm{N}$ addition increased total MT emissions from litter. This discrepancy between the forest floor and litter might be attributed to the interrelation of plant roots and rhizospheric microbes after elevated nitrogen. In the light of future increasing of nitrogen deposition and the unpredictable effects of $\mathrm{N}$ addition on MT fluxes, especially some special MT species, as well as the potential importance of root and rhizospheric microbes on MT fluxes, additional research should be conducted on the influence of nitrogen deposition. This should include simulating nitrogen deposition methods (canopy application versus soil application), nitrogen's forms (inorganic/organic, nitrate versus ammonium, and gaseous versus particulate) and nitrogen amount on MT emission by root and/or rhizospheric microorganisms.

\section{Acknowledgments}

This study was supported by the National Natural Science Foundation of China (Grant Nos. 41877326 and 41473083). We gratefully acknowledge the support from the Guangzhou Institute of Geochemistry, CSA and Dinghushan Biosphere Reserve.

\section{References}

Aaltonen, H., Aalto, J., Kolari, P., Pihlatie, M., Pumpanen, J., Kulmala, M., Nikinmaa, E., Vesala, T., Bäck, J., 2013. Continuous VOC flux measurements on boreal forest floor. Plant and Soil 369, 241- 
256.

Aaltonen, H., Pumpanen, J., Hakola, H., Rasmus, S., Bäck, J., 2012. Snowpack concentrations and estimated fluxes of volatile organic compounds in a boreal forest. Biogeosciences 9, 2033-2044.

Agathokleous, E., Kitao, M., Calabrese, E.J., 2018. Emission of volatile organic compounds from plants shows a biphasic pattern within an hormetic context. Environmental Pollution 239, 318-321.

Albers, C.N., Kramshoj, M., Rinnan, R., 2018. Rapid mineralization of biogenic volatile organic compounds in temperate and Arctic soils. Biogeosciences 15, 3591-3601.

Asensio, D., Penuelas, J., Filella, I., Llusia, J., 2007a. On-line screening of soil VOCs exchange responses to moisture, temperature and root presence. Plant and Soil 291, 249-261.

Asensio, D., Penuelas, J., Llusia, J., Ogaya, R., Filella, I., 2007b. Interannual and interseasonal soil $\mathrm{CO}_{2}$ efflux and $\mathrm{VOC}$ exchange rates in a Mediterranean holm oak forest in response to experimental drought. Soil Biology \& Biochemistry 39, 2471-2484.

Asensio, D., Penuelas, J., Prieto, P., Estiarte, M., Filella, I., Llusia, J., 2008. Interannual and seasonal changes in the soil exchange rates of monoterpenes and other VOCs in a Mediterranean shrubland. European Journal of Soil Science 59, 878-891.

Aydin, Y.M., Yaman, B., Koca, H., Dasdemir, O., Kara, M., Altiok, H., Dumanoglu, Y., Bayram, A., Tolunay, D., Odabasi, M., Elbir, T., 2014. Biogenic volatile organic compound (BVOC) emissions from forested areas in Turkey: Determination of specific emission rates for thirty-one tree species. Science of the Total Environment 490, 239-253.

Blanch, J.S., Peñuelas, J., Llusià, J., 2007. Sensitivity of terpene emissions to drought and fertilization in terpene-storing Pinus halepensis and non-storing Quercus ilex. Physiologia Plantarum 131, 211-225.

Bobbink, R., Hicks, K., Galloway, J., Spranger, T., Alkemade, R., Ashmore, M., Bustamante, M., Cinderby, S., Davidson, E., Dentener, F., Emmett, B., Erisman, J.W., Fenn, M., Gilliam, F., Nordin, A., Pardo, L., De Vries, W., 2010. Global assessment of nitrogen deposition effects on terrestrial plant diversity: a synthesis. Ecological Applications 20, 30-59.

Carriero, G., Brunetti, C., Fares, S., Hayes, F., Hoshika, Y., Mills, G., Tattini, M., Paoletti, E., 2016. BVOC responses to realistic nitrogen fertilization and ozone exposure in silver birch. Environmental Pollution 213, 988-995.

Cho, C.W., Sung, K., Coapcioglu, M.Y., Drew, M., 2005. Influence of water content and plants on the dissipation of chlorinated volatile organic compounds in soil. Water, Air, and Soil Pollution 167, 259 271.

Chomel, M., Guittonny-Larchevêque, M., Fernandez, C., Gallet, C., DesRochers, A., Paré, D., Jackson, B.G., Baldy, V., 2016. Plant secondary metabolites: a key driver of litter decomposition and soil nutrient cycling. Journal of Ecology 104, 1527-1541.

Fall, R., Copley, S.D., 2000. Bacterial sources and sinks of isoprene, a reactive atmospheric hydrocarbon. Environmental Microbiology 2, 123-130.

Galloway, J.N., Dentener, F.J., Capone, D.G., Boyer, E.W., Howarth, , R.W., Seitzinger, , S.P., Asner,, G.P., Cleveland,, C.C., Green,, P. A., Holland,, E.A., Karl,, D.M., Michaels,, A.F., Porter,, J.H., Townsend, , A.R., Vöosmarty,, C.J., 2004. Nitrogen cycles: past, present, and future. Biogeochemistry 70, 153-226.

Galloway, J.N., Townsend, A.R., Erisman, J.W., Bekunda, M., Cai, Z., Freney, J.R., Martinelli, L.A., Seitzinger, S.P., Sutton, M.A., 2008. Transformation of the nitrogen cycle: recent trends, questions, and potential solutions. Science 320, 889-892.

Grandy, A.S., Salam, D.S., Wickings, K., McDaniel, M.D., Culman, S. W., Snapp, S.S., 2013. Soil respiration and litter decomposition responses to nitrogen fertilization rate in no-till corn systems. Agriculture, Ecosystems \& Environment 179, 35-40.

Gray, C.M., Fierer, N., 2012. Impacts of nitrogen fertilization on volatile organic compound emissions from decomposing plant litter. Global Change Biology 18, 739-748.

Gray, C.M.K., Monson, R.K., Fierer, N., 2010. Emissions of volatile organic compounds during the decomposition of plant litter. Journal of Geophysical Research. Biogeosciences 115, G03015.

Greenberg, J.P., Asensio, D., Turnipseed, A., Guenther, A.B., Karl, T., Gochis, D., 2012. Contribution of leaf and needle litter to whole ecosystem BVOC fluxes. Atmospheric Environment 59, 302-311.

Guenther, A.B., 2002. The contribution of reactive carbon emissions from vegetation to the carbon balance of terrestrial ecosystems. Chemosphere 49, 837-844.

Guenther, A.B., Jiang, X., Heald, C.L., Sakulyanontvittaya, T., Duhl, T., Emmons, L.K., Wang, X., 2012. The model of emissions of gases and aerosols from nature version 2.1 (MEGAN2.1): an extended and updated framework for modeling biogenic emissions. Geoscientific Model Development 5, 1-58.

Hassiotis, C.N., Lazari, D.M., 2010. Decomposition process in the Mediterranean region. Chemical compounds and essential oil degradation from Myrtus communis. International Biodeterioration \& Biodegradation 64, 356-362.

Hayward, S., Muncey, R.J., James, A.E., Halsall, C.J., Hewitt, C.N., 2001. Monoterpene emissions from soil in a Sitka spruce forest. Atmospheric Environment 35, 4081-4087.

Hu, B., Jarosch, A.M., Gauder, M., Graeff-Honninger, S., Schnitzler, J. P., Grote, R., Rennenberg, H., Kreuzwieser, J., 2018. VOC emissions and carbon balance of two bioenergy plantations in response to nitrogen fertilization: A comparison of Miscanthus and Salix. Environmental Pollution 237, 205-217.

Huang, W.J., Zhang, D.Q., Li, Y.L., Lu, X.K., Zhang, W., Huang, J., Otieno, D., Xu, Z.H., Liu, J.X., Liu, S.Z., Chu, G.W., 2012. Responses of soil acid phosphomonoesterase activity to simulated nitrogen deposition in three forests of subtropical China. Pedosphere 22, 698-706.

Insam, H., Seewald, M.S.A., 2010. Volatile organic compounds (VOCs) in soils. Biology and Fertility of Soils 46, 199-213.

Kainulainen, P., Holopainen, J.K., 2002. Concentrations of secondary compounds in Scots pine needles at different stages of decomposition. Soil Biology \& Biochemistry 34, 37-42.

Kivimäenpää, M., Ghimire, R.P., Sutinen, S., Häikiö, E., Kasurinen, A., Holopainen, T., Holopainen, J.K., 2016. Increases in volatile organic compound emissions of Scots pine in response to elevated ozone and warming are modified by herbivory and soil nitrogen availability. European Journal of Forest Research 135, 343-360.

Leff, J.W., Fierer, N., 2008. Volatile organic compound (VOC) emissions from soil and litter samples. Soil Biology \& Biochemistry 
40, 1629-1636.

Lin, C., Owen, S.M., Peñuelas, J., 2007. Volatile organic compounds in the roots and rhizosphere of Pinus spp. Soil Biology \& Biochemistry 39, 951-960.

Liu, J.X., Zhang, D.Q., Zhou, G.Y., Faivre-Vuillin, B., Deng, Q., Wang, C.L., 2008. $\mathrm{CO}_{2}$ enrichment increases nutrient leaching from model forest ecosystems in subtropical China. Biogeosciences 5, 1783-1795.

Maki, M., Heinonsalo, J., Hellen, H., Back, J., 2017. Contribution of understorey vegetation and soil processes to boreal forest isoprenoid exchange. Biogeosciences 14, 1055-1073.

Mancuso, S., Taiti, C., Bazihizina, N., Costa, C., Menesatti, P., Giagnoni, L., Arenella, M., Nannipieri, P., Renella, G., 2015. Soil volatile analysis by proton transfer reaction-time of flight mass spectrometry (PTR-TOF-MS). Applied Soil Ecology 86, 182-191.

Mo, J.M., Brown, S., Jinghua, X., Fang, Y.T., Li, Z.A., 2006. Response of litter decomposition to simulated $\mathrm{N}$ deposition in disturbed, rehabilitated and mature forests in subtropical China. Plant and Soil 282, 135-151.

Mo, J.M., Brown, S., Peng, S.L., Kong, G.H., 2003. Nitrogen availability in disturbed, rehabilitated and mature forests of tropical China. Forest Ecology and Management 175, 573-583.

Ormeño, E., Fernandez, C., 2012. Effect of soil nutrient on production and diversity of volatile terpenoids from plants. Current Bioactive Compounds 8, 71-79.

Owen, S.M., Clark, S., Pompe, M., Semple, K.T., 2007. Biogenic volatile organic compounds as potential carbon sources for microbial communities in soil from the rhizosphere of Populus tremula. FEMS Microbiology Letters 268, 34-39.

Peñuelas, J., Asensio, D., Tholl, D., Wenke, K., Rosenkranz, M., Piechulla, B., Schnitzler, J.P., 2014. Biogenic volatile emissions from the soil. Plant, Cell \& Environment 37, 1866-1891.

Peñuelas, J., Llusia, J., 2003. BVOCs: Plant defense against climate warming? Trends in Plant Science 8, 105-109.

Peñuelas, J., Staudt, M., 2010. BVOCs and global change. Trends in Plant Science 15, 133-144.

Ramirez, K.S., Lauber, C.L., Fierer, N., 2010. Microbial consumption and production of volatile organic compounds at the soil-litter interface. Biogeochemistry 99, 97-107.

Schulz-Bohm, K., Gerards, S., Hundscheid, M., Melenhorst, J., de Boer, W., Garbeva, P., 2018. Calling from distance: attraction of soil bacteria by plant root volatiles. ISME Journal 12, 1252-1262.

Schuster, M.J., 2015. Increased rainfall variability and $\mathrm{N}$ addition accelerate litter decomposition in a restored prairie. Oecologia 180, 645-655.

Serrano, A., Gallego, A., 2006. Sorption study of 25 volatile organic compounds in several Mediterranean soils using headspace-gas chromatography-mass spectrometry. Journal of Chromatography.
A 1118, 261-270.

Smolander, A., Kanerva, S., Adamczyk, B., Kitunen, V., 2012. Nitrogen transformations in boreal forest soils-does composition of plant secondary compounds give any explanations? Plant and Soil 350, 1-26.

Smolander, A., Ketola, R.A., Kotiaho, T., Kanerva, S., Suominen, K., Kitunen, V., 2006. Volatile monoterpenes in soil atmosphere under birch and conifers: effects on soil $\mathrm{N}$ transformations. Soil Biology \& Biochemistry 38, 3436-3442.

Wang, S.J., Ruan, H.H., Han, Y., 2010. Effects of microclimate, litter type, and mesh size on leaf litter decomposition along an elevation gradient in the Wuyi Mountains, China. Ecological Research 25, 1113-1120.

Wang, X.M., Wu, T., 2008. Release of isoprene and monoterpenes during the aerobic decomposition of orange wastes from laboratory incubation experiments. Environmental Science \& Technology 42, 3265-3270.

Wang, Y.S., Cheng, S.L., Fang, H.J., Yu, G.R., Xu, X.F., Xu, M.J., Wang, L., Li, X., Si, G., Geng, J., He, S., 2015. Contrasting effects of ammonium and nitrate inputs on soil $\mathrm{CO}_{2}$ emission in a subtropical coniferous plantation of southern China. Biology and Fertility of Soils $51,815-825$.

Wenke, K., Kai, M., Piechulla, B., 2009. Belowground volatiles facilitate interactions between plant roots and soil organisms. Planta 231, 499-506.

Zeng, J., Liu, X.J., Song, L., Lin, X.G., Zhang, H.Y., Shen, C.C., Chu, $H ., 2016$. Nitrogen fertilization directly affects soil bacterial diversity and indirectly affects bacterial community composition. Soil Biology \& Biochemistry 92, 41-49.

Zhang, H.F., Liu, H.M., Zhao, J.N., Wang, L.L., Li, G., Huangfu, C.H., Wang, H., Lai, X., Li, J., Yang, D., 2017a. Elevated precipitation modifies the relationship between plant diversity and soil bacterial diversity under nitrogen deposition in Stipa baicalensis steppe. Applied Soil Ecology 119, 345-353.

Zhang, L., Zou, J.W., Siemann, E., 2017b. Interactive effects of elevated $\mathrm{CO}_{2}$ and nitrogen deposition accelerate litter decomposition cycles of invasive tree (Triadica sebifera). Forest Ecology and Management 385, 189-197.

Zhang, Q., Streets, D.G., He, K.B., Wang, Y.X., Richter, A., Burrows, J. P., Uno, I., Jang, C.J., Chen, D., Yao, Z., Lei, Y., 2007. NOx emission trends for China, 1995-2004: the view from the ground and the view from space. Journal of Geophysical Research, D, Atmospheres 112, 449-456.

Zhang-Turpeinen, , H., Kivimäenpää, , M., Aaltonen, H., Berninger, F., Köster, E., Köster, K., Kösterbd,, K., Menyailoe, , O., Prokushkine, A., Pumpanena,, J., 2019. Wildfire effects on BVOC emissions from boreal forest floor on permafrost soil in Siberia. Science of the Total Environment 711, 134851. 